\title{
EFFECT OF NITROGEN RATE ON NITROGEN USE EFFICIENCY IN WINTER OILSEED RAPE (BRASSICA NAPUS)
}

\author{
Linda Litke, Zinta Gaile, Antons Ruža \\ Latvia University of Life Sciences and Technologies, Latvia \\ linda.litke@1lu.lv
}

\begin{abstract}
Winter oilseed rape is the main oilseed crop in Latvia. High yield production depends on applied plant nutrients, especially nitrogen. Nitrogen is one of the most mobile plant nutrients in the soil and, therefore, nitrogen fertilizer management is an important part of agriculture. The objective of this paper is to evaluate the effect of nitrogen fertilizer rate on nitrogen use efficiency (NUE) in winter oilseed rape. The field experiment was conducted during four growing seasons (2014/2015, 2015/2016, 2016/2017 and 2017/2018) at the Research and Study farm 'Pēterlauki' of Latvia University of Life Sciences and Technologies ( $56^{\circ} 30.658^{\prime} \mathrm{N}$ and $\left.23^{\circ} 41.580^{\prime} \mathrm{E}\right)$. In total, eight nitrogen rates were used in this experiment ( $\mathrm{kg} \mathrm{ha}^{-1}$ of $\mathrm{N}$ pure matter): N0 or control, N60, N90, N120 $(80+40), \mathrm{N} 150(100+50), \mathrm{N} 180$ $(120+60), \mathrm{N} 210(120+60+30)$ and $\mathrm{N} 240(140+60+40)$. All NUE parameters were calculated only for five nitrogen rates (N0; N60, N120, N180 and N 240). Results indicated that the nitrogen fertilizer rate had a significant $(\mathrm{p}<0.001)$ effect on winter oilseed rape seed yield. The yield increased until the rate $\mathrm{N} 120-\mathrm{N} 180$. Nitrogen fertilizer rate also significantly $(\mathrm{p}<0.001)$ affected $\mathrm{N}, \mathrm{P}_{2} \mathrm{O}_{5}$ and $\mathrm{K}_{2} \mathrm{O}$ removal with oilseed rape biomass. $\mathrm{N}$ and $\mathrm{K}_{2} \mathrm{O}$ removal with seed yield significantly increased until the nitrogen rate $\mathrm{N} 120-\mathrm{N} 180$, but $\mathrm{P}_{2} \mathrm{O}_{5}$ until $\mathrm{N} 60-\mathrm{N} 180$. Results showed that the nitrogen fertilizer significantly $(\mathrm{p}<0.001)$ affected NUE, nitrogen uptake efficiency $(\mathrm{NUpE})$ and nitrogen utilization efficiency (NUtE), but it did not have a significant $(\mathrm{p}=0.840)$ effect on nitrogen harvesting index $(\mathrm{NHI})$. By increasing the nitrogen fertilizer rate, NUE, NUpE and NUtE decreased.
\end{abstract}

Key words: seeds, stems, roots, content of nutritional elements, nutrient removal.

\section{Introduction}

Winter oilseed rape (Brassica napus ssp. oleifera) is one of the most important and profitable crops in Latvia, which requires optimal nutrient supply. But nitrogen is one of the most mobile plant nutrients in the soil and nitrogen losses not only increase production costs, but also can lead to environment pollution. In the literature it is mentioned that the fertilizer application rate has a significant influence on the amount of nitrates leached out of the root zone (Podgornik \& Pintar, 2007) and leaching losses can be large in agriculture, often 10 to $20 \%$ from applied nitrogen (Davis, 2007). Therefore, nitrogen fertilizer management is an important part of agriculture.

Nitrogen use efficiency (NUE) is an important indicator in agriculture that is defined as yield produced per unit of available nitrogen. Usually NUE is divided in nitrogen uptake efficiency (NUpE), which shows the ability of the plant to capture nitrogen from the soil, and nitrogen utilization efficiency (NUtE), which shows the ability to utilize the absorbed nitrogen to produce yield (Moll et al., 1982). NUE can be affected by several factors meteorological conditions in the growing season, nitrogen fertilizer type, nitrogen fertilizer rate and time of application (Haile et al., 2012). In Latvia, previous studies showed that the winter oilseed rape seed yield significantly increased until nitrogen rate N120-N150 (Ruža et al., 2012). But in general, little documented research is available about nitrogen fertilizer effect on winter oilseed rape yield and different NUE parameters, therefore research was continued. The objective of this paper is to evaluate the effect of nitrogen fertilizer rate on nitrogen use efficiency in winter oilseed rape.

\section{Materials and Methods}

The field experiment was conducted during four growing seasons $(2014 / 2015,2015 / 2016,2016 / 2017$ and 2017/2018) at the Research and Study farm 'Pēterlauki' of the Latvia University of Life Sciences and Technologies $\left(56^{\circ} 30.658^{\prime} \mathrm{N}\right.$ and $23^{\circ} 41.580^{\prime}$ E). In total, eight nitrogen rates ( $\mathrm{N}$ rates) were used in this experiment: N0 or control, N60, N90, N120 $(80+40), \mathrm{N} 150(100+50), \mathrm{N} 180(120+60)$ and $\mathrm{N} 240$ $(140+60+40)$. All NUE parameters were calculated only for five nitrogen rates: N0, N60, N120, N180 and $\mathrm{N} 240$, therefore also rape yield was analyzed depending on the above mentioned five rates.

The experiment was conducted in Endocalcaric Abruptic Luvisol (WRB, 2015), loam. In autumn, before sowing, the agrochemical analysis of the soil was done. Soil agrochemical indicators varied by growing year (Table 1). The forecrop was cereals. The soil tillage used was traditional with mould-board ploughing at the depth of $20-22 \mathrm{~cm}$. In spring, when the vegetation renewed, nitrogen fertilizer was applied in all variants, except the control variant N0. During the first fertilization, ammonium nitrate $\left(\mathrm{NH}_{4} \mathrm{NO}_{3}\right.$; N34\%) was used. The second fertilization was done at GS $32-35$ with ammonium sulphate $\left(\left(\mathrm{NH}_{4}\right)_{2} \mathrm{SO}_{4}\right.$; $\mathrm{N} 21 \%, \mathrm{~S} 24 \%$ ) at the rate of $200 \mathrm{~kg} \mathrm{ha}^{-1}$ and the remaining amount of needed nitrogen was added using ammonium nitrate. The third fertilization was done at GS $52-55$ using ammonium nitrate. The whole rate of nitrogen fertilizer was applied once for variant 
Soil agrochemical indicators depending on winter oilseed rape growing season

Table 1

\begin{tabular}{|c|c|c|c|c|c|}
\hline \multirow{2}{*}{ Indicators } & \multicolumn{4}{|c|}{ Growing season } & \multirow[t]{2}{*}{ Methods } \\
\hline & $2014 / 2015$ & $2015 / 2016$ & $2016 / 2017$ & $2017 / 2018$ & \\
\hline $\mathrm{pH} \mathrm{KCl}$ & 6.9 & 6.7 & 6.7 & 6.8 & $\begin{array}{l}\text { Potentiometric in } 1 M \mathrm{KCl} \\
\text { suspension }\end{array}$ \\
\hline $\begin{array}{l}\text { Organic matter } \\
\text { content, } \mathrm{g} \mathrm{kg}^{-1}\end{array}$ & 32 & 20 & 23 & 39 & Tyurin's method \\
\hline $\begin{array}{c}\mathrm{P}_{2} \mathrm{O}_{5} \text { content, } \mathrm{mg} \\
\mathrm{kg}^{-1}\end{array}$ & 134 & 77 & 498 & 97 & Egner-Riehm (DL) method \\
\hline$\underset{\mathrm{K}_{2} \mathrm{O} \text { content, } \mathrm{mg}}{\mathrm{kg}^{-1}}$ & 238 & 143 & 163 & 157 & Egner - Riehm (DL) method \\
\hline
\end{tabular}

N60, fertilizer rate was divided into two applications for variants $\mathrm{N} 120$ and N180, and rate was divided into three applications for the variant N240.

Before harvesting, plant samples were taken from each plot from $0.5 \mathrm{~m}^{2}$ square; these plant samples were used to calculate the mass $\left(\mathrm{t} \mathrm{ha} \mathrm{h}^{-1}\right)$ of stems with pods and roots. Seed samples were taken after yield harvesting. Samples were used to determine the content of $\mathrm{N}, \mathrm{P}, \mathrm{K}$ in seeds, stems with pods and roots. The analysis of $\mathrm{N}, \mathrm{P}, \mathrm{K}$ was done in the Scientific Laboratory of Biotechnology Department of Agronomic Analysis of the Latvia University of Life Science and Technologies according to the standard methods. Nutrient removal was calculated from seed, stems with pods and main root mass, as well as the concentration of nutrient in them. Different NUE parameters were calculated according to formulas (1) - (4) (Rahimizadeh et al., 2010):

Nitrogen use efficiency (NUE, $\mathrm{kg} \mathrm{kg}^{-1}$ ) =

$=\mathrm{S}_{\mathrm{y}} / \mathrm{N}_{\text {supply' }}$

where

$\mathrm{S}_{\mathrm{y}}$ - oilseed rape seed yield, $\mathrm{kg} \mathrm{ha}^{-1}$

$\mathrm{N}_{\text {supply }}$ - sum of nitrogen used from soil in control variant $(\mathrm{N}-0)$ and from nitrogen fertilizer, $\mathrm{kg}$

Nitrogen uptake efficiency $\left(\mathrm{NUpE}, \mathrm{kg} \mathrm{kg}^{-1}\right)=$

$=\mathrm{N}_{\mathrm{t}} / \mathrm{N}_{\text {supply }}$

where

$\mathrm{N}_{\mathrm{t}}$ - total plant nitrogen uptake, $\mathrm{kg}$

Nitrogen utilization efficiency $\left(\mathrm{NUtE}, \mathrm{kg} \mathrm{kg}^{-1}\right)=$ $=\mathrm{S}_{\mathrm{y}} / \mathrm{N}_{\mathrm{t}}$

Nitrogen harvesting index $(\mathrm{NHI}, \%)=$ $=\left(\mathrm{N}_{\mathrm{s}} / \mathrm{N}_{\mathrm{t}}\right) \times 100$

where

$\mathrm{N}_{\mathrm{s}}$ - total seed nitrogen uptake, $\mathrm{kg}$

Analysis of variance was used for data statistical processing (R-studio). Bonferroni test was used for comparison of means and the difference was considered statistically significant when $\mathrm{p}<0.05$. Significantly different means were labelled with different letters in superscript (a,b,c,d,e).

Meteorological situation, if compared with long term average data, differed during the trial period depending on a year. The first three years were more suitable for winter oilseed rape yield formation. Long and cool autumn and temperately warm spring with enough precipitation during the vegetation season were observed in 2014/2015. The autumn of 2015/2016 was warm and dry, and spring was also warm and with a small amount of rainfall. The autumn of 2016/2017 was quite warm, but dry in comparison to other trial years; spring and summer of 2017 were moderately warm (temperature was close to long-term average), the amount of precipitation was lower, if compared with long-term average data (except July), but lack of moisture was not observed. The last year of the investigation (2017/2018) was significantly different. (1) During the autumn of 2017 warm temperatures and plenty of rain were observed; however, since May of the next spring (2018) untypically long drought period with high air temperatures started and lasted even until the harvest, negatively affecting the yield of oilseed rape and NUE.

\section{Results and Discussion \\ Oilseed rape seed yield}

Winter oilseed rape has a high $\mathrm{N}$ requirement (Grant \& Bailey, 1993). As a result, $\mathrm{N}$ rate has a significant impact on rape seed yield (Pellet, 2002). Excess use of nitrogen can reduce oilseed rape seed yield and quality, and it can delay maturity (Grant \& Bailey, 1993). Previous studies in Latvia have showed that winter oilseed seed yield significantly increased until the rate of N120-N150. A higher N rate either did not give a significant yield increase or even reduced the yield (Ruža et al., 2012). In our research, the increase of $\mathrm{N}$ rate significantly $(\mathrm{p}<0.001)$ increased the winter oilseed rape seed yield (Figure 1). An important yield increase was observed until the 


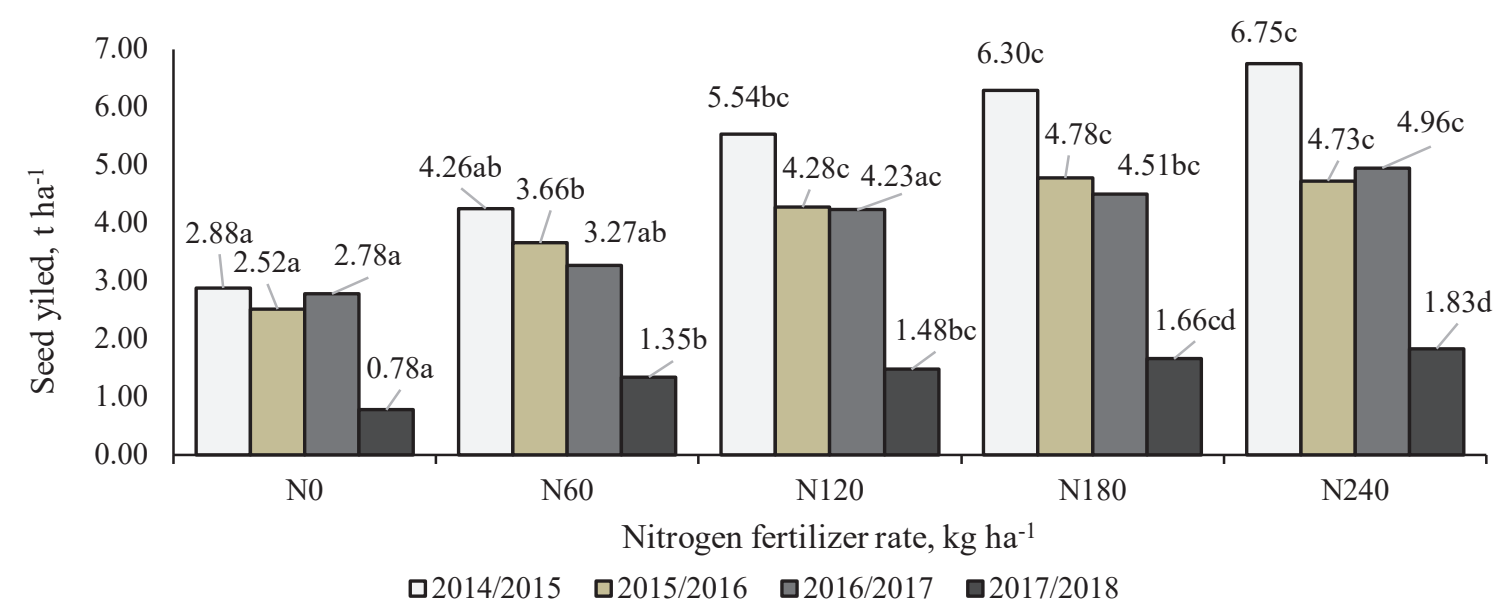

Figure 1. Winter oilseed rape seed yield depending on nitrogen fertilizer rate, $t$ ha ${ }^{-1}(a, b, c, d-$ yields labelled with different letters are significantly different in growing season depending on the nitrogen fertilizer rate).

rate of N120-N180. However, great yield differences depending on growing season did not allow to come to an objective conclusion - until which $\mathrm{N}$ rate the winter oilseed rape seed yield significantly increases. As a result, research should be continued.

The oilseed rape seed yield was determined not only by the used $\mathrm{N}$ rate, but also by meteorological conditions in the growing season. In our research, meteorological conditions significantly $(p<0.001)$ affected the rape yield, which was extremely variable over the years. The most favorable year for rape growing was 2014/2015, when the highest oilseed rape yield was observed $\left(2.88-6.75 \mathrm{tha}^{-1}\right.$ depending on the nitrogen fertilizer rate) (Figure 1). Years 2015/2016 and 2016/2017 also were characterized by suitable conditions for the rape growing (yields were $2.52-4.78$ and $2.78-4.96 \mathrm{t} \mathrm{ha}^{-1}$, respectively). An unfavorable year for rape yield formation was that of 2017/2018, when excessive moisture was observed in sowing autumn, but drought and heat in springsummer season. As a result, extremely low seed yields were obtained $\left(0.78-1.83 \mathrm{t} \mathrm{ha}^{-1}\right)$. This coincides with data from literature that soil moisture limits yield in dry conditions, and nitrogen fertilizer will increase the yield only to the limits secured by the moisture supply. At the same time, an increased moisture supply increases the yield potential of rape and the amount of $\mathrm{N}$ required for optimum yields (Grant \& Bailey, 1993).

Nutrient removal

Nitrogen concentration in plant increases with the increase of N rate (Šidlauskas \& Tarakanovas, 2004), and nutrient concentration in rape seeds significantly varies over the years (Szczepaniak et al., 2017). G.D. Jackson (2000) found that relatively large amounts of potassium are accumulated by rape, but only a small portion of that is removed by the seed. Our results showed that nitrogen fertilizer had a significant impact on nitrogen $(\mathrm{p}<0.001)$, phosphorus $(p<0.001)$ and potassium $(p<0.05)$ concentration in rape seeds. By increasing the nitrogen fertilizer rate, nitrogen concentration in rape seeds also increased, but phosphorus and potassium concentration - decreased.

$\mathrm{N}$ rate affected significantly $(\mathrm{p}<0.001) \mathrm{N}, \mathrm{P}_{2} \mathrm{O}_{5}$ and $\mathrm{K}_{2} \mathrm{O}$ removal with seed yield. By increasing the nitrogen fertilizer rate, removal of all three nutrients with seed yield also increased (Table 2). $\mathrm{N}$ and $\mathrm{K}_{2} \mathrm{O}$

\section{Nutrient removal with winter oilseed rape seeds depending on nitrogen fertilizer rate and growing season, $\mathrm{kg} \mathrm{ha}^{-1}$}

\begin{tabular}{|c|c|c|c|c|c|c|c|c|c|c|c|c|}
\hline \multirow{2}{*}{ N rate } & \multicolumn{5}{|c|}{ N removal } & \multicolumn{4}{c|}{$\mathrm{P}_{2} \mathrm{O}_{5}$ removal } & \multicolumn{4}{c|}{$\mathrm{K}_{2} \mathrm{O}$ removal } \\
\cline { 2 - 14 } & $2014 /$ & $2015 /$ & $2016 /$ & $2017 /$ & $2014 /$ & $2015 /$ & $2016 /$ & $2017 /$ & $2014 /$ & $2015 /$ & $2016 /$ & $2017 /$ \\
& 2015 & 2016 & 2017 & 2018 & 2015 & 2016 & 2017 & 2018 & 2015 & 2016 & 2017 & 2018 \\
\hline N0 & $78.98^{\mathrm{a}}$ & $59.66^{\mathrm{a}}$ & $85.98^{\mathrm{a}}$ & $22.78^{\mathrm{a}}$ & $54.81^{\mathrm{a}}$ & $38.07^{\mathrm{a}}$ & $54.19^{\mathrm{a}}$ & $11.58^{\mathrm{a}}$ & $33.32^{\mathrm{a}}$ & $18.79^{\mathrm{a}}$ & $27.47^{\mathrm{a}}$ & $6.27^{\mathrm{a}}$ \\
\hline $\mathrm{N} 60$ & $114.03^{\mathrm{ab}}$ & $89.27^{\mathrm{b}}$ & $93.85^{\mathrm{a}}$ & $38.35^{\mathrm{b}}$ & $74.09^{\mathrm{ab}}$ & $53.64^{\mathrm{b}}$ & $60.68^{\mathrm{ab}}$ & $18.19^{\mathrm{b}}$ & $46.62^{\mathrm{ab}}$ & $28.19^{\mathrm{b}}$ & $32.28^{\mathrm{ab}}$ & $10.53^{\mathrm{b}}$ \\
\hline $\mathrm{N} 120$ & $148.47^{\mathrm{bc}}$ & $114.65^{\mathrm{c}}$ & $130.28^{\mathrm{ab}}$ & $42.69^{\mathrm{bc}}$ & $81.23^{\mathrm{b}}$ & $61.74^{\mathrm{bc}}$ & $74.62^{\mathrm{ac}}$ & $18.95^{\mathrm{b}}$ & $55.36^{\mathrm{bc}}$ & $33.99^{\mathrm{c}}$ & $39.22^{\mathrm{ac}}$ & $11.56^{\mathrm{bc}}$ \\
\hline $\mathrm{N} 180$ & $194.52^{\mathrm{cd}}$ & $144.86^{\mathrm{d}}$ & $141.99^{\mathrm{b}}$ & $48.61^{\mathrm{cd}}$ & $86.53^{\mathrm{b}}$ & $69.00^{\mathrm{c}}$ & $78.48^{\mathrm{ad}}$ & $19.76^{\mathrm{bc}}$ & $63.67^{\mathrm{c}}$ & $40.29^{\mathrm{d}}$ & $42.87^{\mathrm{bc}}$ & $12.98^{\mathrm{cd}}$ \\
\hline $\mathrm{N} 240$ & $218.70^{\mathrm{d}}$ & $150.95^{\mathrm{d}}$ & $157.57^{\mathrm{b}}$ & $55.41^{\mathrm{d}}$ & $89.69^{\mathrm{b}}$ & $67.21^{\mathrm{c}}$ & $84.00^{\mathrm{bcd}}$ & $22.70^{\mathrm{c}}$ & $66.64^{\mathrm{c}}$ & $39.88^{\mathrm{d}}$ & $48.32^{\mathrm{c}}$ & $14.36^{\mathrm{d}}$ \\
\hline
\end{tabular}

a,b,c,d - indicators labelled with different letters are significantly different in columns depending on nitrogen rate. 
removal with seed yield significantly increased until the nitrogen fertilizer rate $\mathrm{N} 120-\mathrm{N} 180$ (Table 2). $\mathrm{P}_{2} \mathrm{O}_{5}$ removal with seed yield highly varied depending on the growing season, and significant $\mathrm{P}_{2} \mathrm{O}_{5}$ removal increase was observed until the nitrogen rate of N60-N180. Growing season also significantly $(\mathrm{p}<0.001)$ affected $\mathrm{N}, \mathrm{P}_{2} \mathrm{O}_{5}$ and $\mathrm{K}_{2} \mathrm{O}$ removal with oilseed rape seeds. Higher nutrient removal was observed in years when higher seed yields were obtained.

Results showed that $\mathrm{N}$ rate significantly affected $\mathrm{N}$ $(p<0.001), P(p<0.05)$ and $K(p<0.001)$ concentration in oilseed rape stems and pods. By increasing $\mathrm{N}$ rate, $\mathrm{N}$ and $\mathrm{P}$ concentration in winter oilseed rape stems and pods also increased, but that of $\mathrm{P}$ - decreased. In our trial, $\mathrm{N}$ rate significantly affected $\mathrm{N},(\mathrm{p}<0.001), \mathrm{P}_{2} \mathrm{O}_{5}$ $(\mathrm{p}<0.05)$ and $\mathrm{K}_{2} \mathrm{O}(\mathrm{p}<0.001)$ removal with rape stems and pods (Table 3 ). Growing season significantly $(\mathrm{p}<0.001)$ affected $\mathrm{N}, \mathrm{P}_{2} \mathrm{O}_{5}$ and $\mathrm{K}_{2} \mathrm{O}$ removal with oilseed rape stems and pods. The highest nutrient removal with the mentioned aboveground plant parts was observed in 2016/2017, when the highest stem and pods mass $\left(\mathrm{t} \mathrm{ha}^{-1}\right)$ was also observed.

$\mathrm{N}$ rate significantly $(\mathrm{p}<0.001)$ affected $\mathrm{N}, \mathrm{P}$ and $\mathrm{K}$ concentration in winter rape main root mass. By increasing the nitrogen fertilizer rate, $\mathrm{N}$ and $\mathrm{K}$ concentration in main root mass also increased, but that of $\mathrm{P}-$ decreased. Nitrogen fertilizer had a significant $(\mathrm{p}<0.001)$ impact on $\mathrm{N}$ and $\mathrm{K}_{2} \mathrm{O}$ removal with rape main root mass, but the effect was not significant $(\mathrm{p}=0.081)$ on $\mathrm{P}_{2} \mathrm{O}_{5}$ removal. Growing season significantly $(\mathrm{p}<0.001)$ affected only $\mathrm{N}$ and $\mathrm{K}_{2} \mathrm{O}$ removal with main root mass. The highest removal with main root mass was observed in 2017/2018 and 2016/2017 growing seasons.

When evaluating the total $\mathrm{N}, \mathrm{P}_{2} \mathrm{O}_{5}$ and $\mathrm{K}_{2} \mathrm{O}$ removal with winter rape biomass, we found similar results to those reported on separate plant parts: $\mathrm{N}$ rate had a significant $(\mathrm{p}<0.001)$ impact on total $\mathrm{N}, \mathrm{P}_{2} \mathrm{O}_{5}$ and $\mathrm{K}_{2} \mathrm{O}$ removal. Increasing $\mathrm{N}$ rate, total $\mathrm{N}, \mathrm{P}_{2} \mathrm{O}_{5}$ and $\mathrm{K}_{2} \mathrm{O}$ removal with crop biomass also increased in almost all growing seasons. Total $\mathrm{N}$ removal with biomass significantly increased until nitrogen fertilizer rate $\mathrm{N} 180$ (Table 5), that of $\mathrm{P}_{2} \mathrm{O}_{5}-$ until nitrogen fertilizer rate $\mathrm{N} 60-\mathrm{N} 180$, but that of $\mathrm{K}_{2} \mathrm{O}$ increased until N120-N240. Also, the growing season had a significant impact on $\mathrm{N}, \mathrm{P}_{2} \mathrm{O}_{5}$ and $\mathrm{K}_{2} \mathrm{O}$ removal with oilseed rape biomass.

Nitrogen use efficiency (NUE)

Overly high NUE can indicate a fact that more nitrogen is removed than applied, and plants are

\section{Nutrient removal with winter oilseed rape stem and pods depending on nitrogen fertilizer rate and growing season, $\mathrm{kg} \mathrm{ha}^{-1}$}

\begin{tabular}{|c|c|c|c|c|c|c|c|c|c|c|c|c|}
\hline \multirow[b]{2}{*}{$\mathrm{N}$ rate } & \multicolumn{4}{|c|}{$\mathrm{N}$ removal } & \multicolumn{4}{|c|}{$\mathrm{P}_{2} \mathrm{O}_{5}$ removal } & \multicolumn{4}{|c|}{$\mathrm{K}_{2} \mathrm{O}$ removal } \\
\hline & $\begin{array}{l}2014 / \\
2015\end{array}$ & $\begin{array}{l}2015 / \\
2016\end{array}$ & $\begin{array}{l}2016 / \\
2017\end{array}$ & $\begin{array}{c}2017 / \\
2018\end{array}$ & $\begin{array}{l}2014 / \\
2015\end{array}$ & $\begin{array}{l}2015 / \\
2016\end{array}$ & $\begin{array}{l}2016 / \\
2017\end{array}$ & $\begin{array}{l}2017 / \\
2018\end{array}$ & $\begin{array}{l}2014 / \\
2015\end{array}$ & $\begin{array}{l}2015 / \\
2016\end{array}$ & $\begin{array}{l}2016 / \\
2017\end{array}$ & $\begin{array}{l}2017 / \\
2018\end{array}$ \\
\hline N0 & $9.79^{\mathrm{a}}$ & $15.81^{\mathrm{a}}$ & $49.06^{\mathrm{a}}$ & $16.78^{\mathrm{a}}$ & $6.06^{\mathrm{a}}$ & $7.07^{\mathrm{a}}$ & $31.41^{\mathrm{a}}$ & $8.18^{\mathrm{a}}$ & $30.25^{\mathrm{a}}$ & $52.91^{\mathrm{a}}$ & $121.62^{\mathrm{a}}$ & $64.90^{\mathrm{a}}$ \\
\hline N60 & $19.35^{\mathrm{b}}$ & $29.28^{\mathrm{b}}$ & $59.08^{\mathrm{ab}}$ & $24.29^{\mathrm{b}}$ & $9.07^{\mathrm{b}}$ & $10.21^{\mathrm{b}}$ & $43.79^{b}$ & $9.89^{\mathrm{b}}$ & $61.42^{\mathrm{b}}$ & $95.79^{\mathrm{b}}$ & $168.40^{\mathrm{b}}$ & $87.08^{b}$ \\
\hline N120 & $19.34^{b}$ & $38.00^{\circ}$ & $68.41^{\mathrm{bc}}$ & $38.02^{\mathrm{c}}$ & $5.97^{\mathrm{a}}$ & $10.33^{c}$ & $50.70^{\mathrm{b}}$ & $15.84^{\mathrm{c}}$ & $64.05^{\mathrm{b}}$ & $125.61^{\mathrm{c}}$ & $277.37^{\mathrm{c}}$ & $134.83^{\mathrm{c}}$ \\
\hline N180 & $19.07^{\mathrm{b}}$ & $46.53^{d}$ & $83.47^{\mathrm{cd}}$ & $40.09^{c}$ & $6.12^{\mathrm{a}}$ & $15.91^{\mathrm{d}}$ & $51.40^{\mathrm{b}}$ & $15.60^{c}$ & $55.58^{\mathrm{b}}$ & $127.94^{\mathrm{d}}$ & $251.78^{c}$ & $153.93^{\mathrm{d}}$ \\
\hline N240 & $30.56^{\mathrm{c}}$ & $48.65^{\mathrm{e}}$ & $86.26^{\mathrm{d}}$ & $41.01^{\mathrm{c}}$ & $5.60^{\mathrm{a}}$ & $14.54^{\mathrm{e}}$ & $50.55^{\mathrm{b}}$ & $14.18^{\mathrm{d}}$ & $76.05^{\mathrm{b}}$ & $157.88^{\mathrm{e}}$ & $282.58^{\mathrm{c}}$ & $149.99^{\mathrm{d}}$ \\
\hline
\end{tabular}

a,b,c,d - indicators labelled with different letters are significantly different in columns depending on nitrogen rate.

\section{Nutrient removal with winter oilseed rape main root mass depending on} nitrogen fertilizer rate and growing season, $\mathrm{kg} \mathrm{ha}^{-1}$

Table 4

\begin{tabular}{|c|c|c|c|c|c|c|c|c|c|c|c|c|}
\hline \multirow{3}{*}{ N rate } & \multicolumn{5}{|c|}{ N removal } & \multicolumn{4}{c|}{$\mathrm{P}_{2} \mathrm{O}_{5}$ removal } & \multicolumn{4}{c|}{$\mathrm{K}_{2}$ O removal } \\
\cline { 2 - 15 } & $2014 /$ & $2015 /$ & $2016 /$ & $2017 /$ & $2014 /$ & $2015 /$ & $2016 /$ & $2017 /$ & $2014 /$ & $2015 /$ & $2016 /$ & $2017 /$ \\
& 2015 & 2016 & 2017 & 2018 & 2015 & 2016 & 2017 & 2018 & 2015 & 2016 & 2017 & 2018 \\
\hline $\mathrm{N} 0$ & $2.46^{\mathrm{a}}$ & $4.58^{\mathrm{a}}$ & $7.41^{\mathrm{a}}$ & $7.38^{\mathrm{a}}$ & $2.16^{\mathrm{ab}}$ & $1.52^{\mathrm{a}}$ & $4.70^{\mathrm{a}}$ & $3.55^{\mathrm{a}}$ & $4.74^{\mathrm{a}}$ & $8.70^{\mathrm{a}}$ & $15.47^{\mathrm{a}}$ & $10.53^{\mathrm{a}}$ \\
\hline $\mathrm{N} 60$ & $4.16^{\mathrm{b}}$ & $5.64^{\mathrm{b}}$ & $7.39^{\mathrm{a}}$ & $7.64^{\mathrm{a}}$ & $2.97^{\mathrm{b}}$ & $1.82^{\mathrm{b}}$ & $4.84^{\mathrm{a}}$ & $3.54^{\mathrm{a}}$ & $8.46^{\mathrm{b}}$ & $12.96^{\mathrm{b}}$ & $18.96^{\mathrm{a}}$ & $11.42^{\mathrm{a}}$ \\
\hline $\mathrm{N} 120$ & $3.36^{\mathrm{ab}}$ & $4.25^{\mathrm{c}}$ & $8.38^{\mathrm{a}}$ & $10.23^{\mathrm{b}}$ & $2.32^{\mathrm{ab}}$ & $1.06^{\mathrm{c}}$ & $5.15^{\mathrm{a}}$ & $3.74^{\mathrm{a}}$ & $6.59^{\mathrm{ab}}$ & $9.83^{\mathrm{c}}$ & $20.44^{\mathrm{a}}$ & $14.29^{\mathrm{b}}$ \\
\hline $\mathrm{N} 180$ & $3.61^{\mathrm{ab}}$ & $6.34^{\mathrm{d}}$ & $8.16^{\mathrm{a}}$ & $11.38^{\mathrm{c}}$ & $2.62^{\mathrm{ab}}$ & $1.54^{\mathrm{d}}$ & $4.87^{\mathrm{a}}$ & $4.81^{\mathrm{b}}$ & $4.96^{\mathrm{ac}}$ & $11.95^{\mathrm{d}}$ & $16.47^{\mathrm{a}}$ & $14.75^{\mathrm{bc}}$ \\
\hline $\mathrm{N} 240$ & $4.03^{\mathrm{b}}$ & $8.04^{\mathrm{e}}$ & $9.54^{\mathrm{a}}$ & $12.38^{\mathrm{c}}$ & $1.74^{\mathrm{a}}$ & $1.90^{\mathrm{e}}$ & $5.34^{\mathrm{a}}$ & $4.69^{\mathrm{b}}$ & $7.44^{\mathrm{bc}}$ & $15.87^{\mathrm{e}}$ & $22.45^{\mathrm{a}}$ & $15.97^{\mathrm{c}}$ \\
\hline
\end{tabular}

$\mathrm{a}, \mathrm{b}, \mathrm{c}, \mathrm{d}$ - indicators labelled with different letters are significantly different in columns depending on nitrogen rate. 


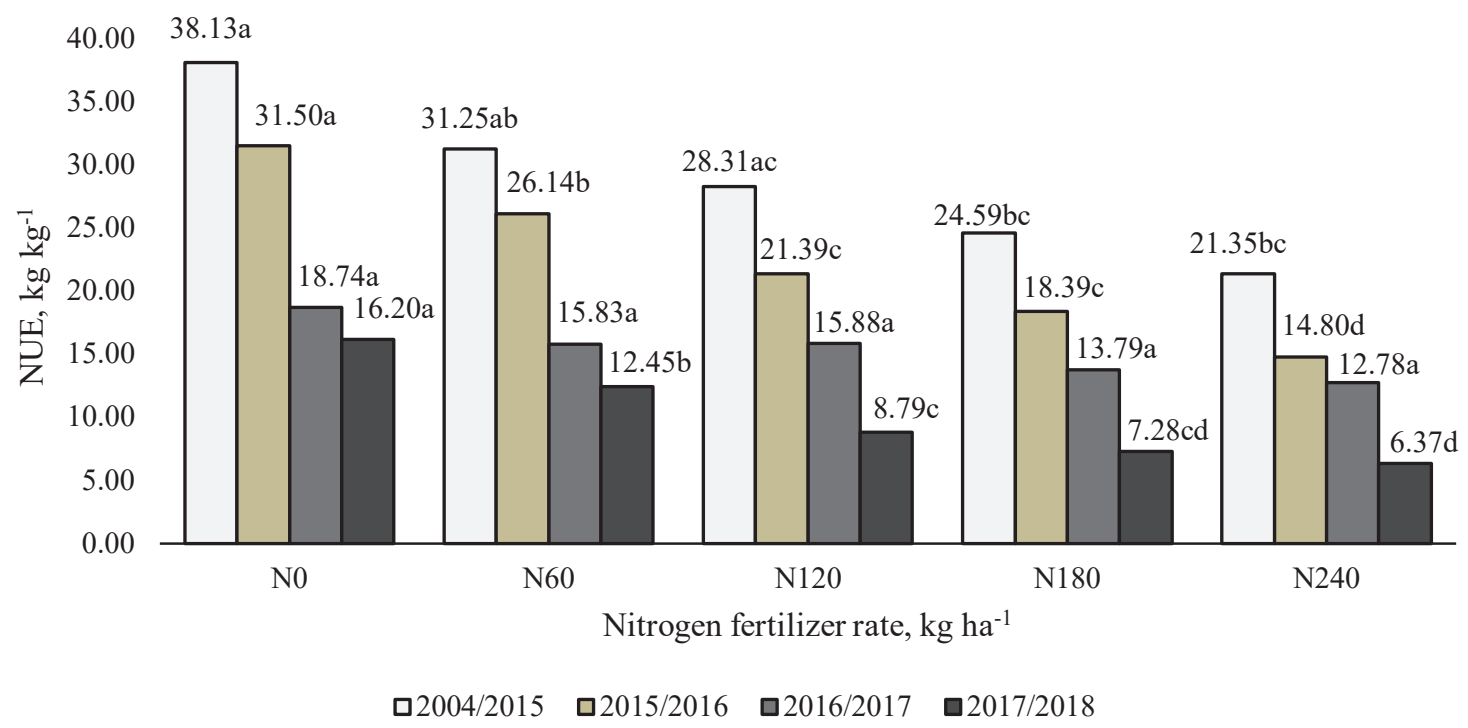

Figure 2. Nitrogen use efficiency of winter oilseed rape depending on nitrogen fertilizer rate, $\mathrm{kg} \mathrm{kg}^{-1}$ (a,b,c,d - NUE labelled with different letters are significantly different in growing season depending on nitrogen fertilizer rate).

using nitrogen from the soil organic matter or residual nitrogen from fertilizer application to a forecrop. Low NUE indicates an excessive use of nitrogen fertilizers, because less nitrogen is used than applied. As a result, unused nitrogen remains in the soil and may be lost from it, as reported by many researchers (e.g. Evans et al., 2016). In our study, NUE was significantly $(\mathrm{p}<0.001)$ affected by $\mathrm{N}$ rate. Higher NUE was observed, when the lowest fertilizer rates were applied (Figure 2). It coincides with other studies, where it was also found that the nitrogen fertilizer rate had a significant effect on NUE, and the trend of decreasing NUE with increasing nitrogen fertilizer rate was observed (Gan et al., 2008).

As the meteorological conditions during trial period were diverse, significant $(p<0.001)$ impact of trial year on rape NUE was observed in our trial. The highest NUE was noted in the 2014/2015 growing season $\left(21.35-38.13 \mathrm{~kg} \mathrm{~kg}^{-1}\right)$, when the highest seed yields were obtained. A slightly lower NUE was observed in 2015/2016 (14.80 - 31.50 $\left.\mathrm{kg} \mathrm{kg}^{-1}\right)$. Lower NUE was in 2016/2017 (12.78-18.74 $\left.\mathrm{kg} \mathrm{kg}^{-1}\right)$, but NUE was very low $\left(6.37-16.20 \mathrm{~kg} \mathrm{~kg}^{-1}\right)$ in the $2017 / 2018$ season due to drought.

Nitrogen uptake efficiency (NUpE)

Results showed that the $\mathrm{N}$ rate had a significant $(p<0.001)$ impact on NUpE (Table 5). Like the NUE, the highest NUpE was also observed at the lowest $\mathrm{N}$ rates, and an increase of $\mathrm{N}$ rate significantly decreased the NUpE. Growing season affected the NUpE significantly $(p<0.001)$. The highest $\mathrm{NUpE}$ was observed in the best season $(2014 / 2015)$, when it was $0.80-1.20 \mathrm{~kg} \mathrm{~kg}^{-1}$ depending on $\mathrm{N}$ rate. Similar NUpE depending on $\mathrm{N}$ rate was observed in 2015/2016 and 2016/2017 (0.65 - 1.00 and $0.65-0.96 \mathrm{~kg} \mathrm{~kg}^{-1}$, respectively). Drought and heat in 2017/2018 reduced the NUpE $\left(0.38-0.98 \mathrm{~kg} \mathrm{~kg}^{-1}\right)$.

Nitrogen utilization efficiency (NUtE)

NUtE was significantly $(\mathrm{p}<0.001)$ affected by $\mathrm{N}$ rate in our trial (Table 6). The tendency, when an

\section{Winter oilseed rape nitrogen uptake efficiency (NUpE) depending on} nitrogen fertilizer rate and growing season, $\mathrm{kg} \mathrm{kg}^{-1}$

\begin{tabular}{|c|c|c|c|c|}
\hline \multirow{2}{*}{ N rate } & \multicolumn{4}{|c|}{ Growing season } \\
\cline { 2 - 5 } & $2014 / 2015$ & $2015 / 2016$ & $2016 / 2017$ & $2017 / 2018$ \\
\hline N0 & $1.20^{\mathrm{a}}$ & $1.00^{\mathrm{a}}$ & $0.96^{\mathrm{a}}$ & $0.98^{\mathrm{a}}$ \\
\hline N60 & $1.01^{\mathrm{b}}$ & $0.89^{\mathrm{b}}$ & $0.77^{\mathrm{b}}$ & $0.65^{\mathrm{b}}$ \\
\hline N120 & $0.87^{\mathrm{c}}$ & $0.78^{\mathrm{c}}$ & $0.78^{\mathrm{c}}$ & $0.54^{\mathrm{c}}$ \\
\hline N180 & $0.85^{\mathrm{c}}$ & $0.76^{\mathrm{c}}$ & $0.71^{\mathrm{d}}$ & $0.44^{\mathrm{d}}$ \\
\hline N240 & $0.80^{\mathrm{c}}$ & $0.65^{\mathrm{d}}$ & $0.65^{\mathrm{d}}$ & $0.38^{\mathrm{d}}$ \\
\hline
\end{tabular}

a,b,c,d - indicators labelled with different letters are significantly different in columns depending on nitrogen rate. 


\section{Winter oilseed rape nitrogen utilization efficiency depending on nitrogen fertilizer rate and growing season, $\mathrm{kg} \mathrm{kg}^{-1}$}

\begin{tabular}{|c|c|c|c|c|}
\hline \multirow{2}{*}{ N rate } & \multicolumn{4}{|c|}{ Growing season } \\
\cline { 2 - 5 } & $2014 / 2015$ & $2015 / 2016$ & $2016 / 2017$ & $2017 / 2018$ \\
\hline N0 & $31.51^{\mathrm{a}}$ & $31.39^{\mathrm{a}}$ & $19.48^{\mathrm{a}}$ & $16.59^{\mathrm{a}}$ \\
\hline N60 & $30.81^{\mathrm{ab}}$ & $29.44^{\mathrm{b}}$ & $20.31^{\mathrm{ab}}$ & $19.13^{\mathrm{b}}$ \\
\hline N120 & $32.35^{\mathrm{a}}$ & $27.25^{\mathrm{c}}$ & $20.20^{\mathrm{a}}$ & $16.19^{\mathrm{a}}$ \\
\hline N180 & $28.93^{\mathrm{b}}$ & $24.17^{\mathrm{d}}$ & $19.23^{\mathrm{a}}$ & $16.56^{\mathrm{a}}$ \\
\hline N240 & $26.65^{\mathrm{c}}$ & $22.78^{\mathrm{e}}$ & $19.53^{\mathrm{a}}$ & $16.86^{\mathrm{a}}$ \\
\hline
\end{tabular}

a,b,c,d - indicators labelled with different letters are significantly different in columns depending on nitrogen rate.

\section{Winer oilseed rape nitrogen harvesting index (NHI) depending on nitrogen fertilizer rate and growing season, $\%$}

\begin{tabular}{|c|c|c|c|c|}
\hline \multirow{2}{*}{ N rate } & \multicolumn{4}{|c|}{ Growing season } \\
\cline { 2 - 5 } & $2014 / 2015$ & $2015 / 2016$ & $2016 / 2017$ & $2017 / 2018$ \\
\hline N0 & $86.33^{\mathrm{ab}}$ & $74.40^{\mathrm{a}}$ & $60.20^{\mathrm{a}}$ & $48.61^{\mathrm{a}}$ \\
\hline N60 & $82.57^{\mathrm{b}}$ & $71.84^{\mathrm{a}}$ & $58.29^{\mathrm{a}}$ & $54.53^{\mathrm{b}}$ \\
\hline N120 & $86.71^{\mathrm{ab}}$ & $73.03^{\mathrm{a}}$ & $62.22^{\mathrm{a}}$ & $46.79^{\mathrm{a}}$ \\
\hline N180 & $89.39^{\mathrm{a}}$ & $73.23^{\mathrm{a}}$ & $60.56^{\mathrm{a}}$ & $48.52^{\mathrm{a}}$ \\
\hline N240 & $86.33^{\mathrm{ab}}$ & $72.66^{\mathrm{a}}$ & $62.10^{\mathrm{a}}$ & $50.90^{\mathrm{ab}}$ \\
\hline
\end{tabular}

a,b,c,d - indicators labelled with different letters are significantly different in columns depending on nitrogen rate.

increase of $\mathrm{N}$ rate decreased NUtE, was observed in almost all growing seasons. The conditions of growing season also had a significant $(p<0.001)$ impact on NUtE. The highest NUtE was observed in 2014/2015 and 2015/2016 (26.65 - 31.51 and 22.78 $31.39 \mathrm{~kg} \mathrm{~kg}^{-1}$, respectively), when the highest yield was obtained. Lowest NUtE was in 2016/2017 $\left(19.23-20.31 \mathrm{~kg} \mathrm{~kg}^{-1}\right)$ and the $2017 / 2018$ growing seasons (16.19 - $19.13 \mathrm{~kg} \mathrm{~kg}^{-1}$, respectively). Despite the similar seed yield in 2015/2016 and 2016/2017 (Figure 1), NUtE was considerably lower in 2016/2017, due to the higher stem and pod, and root mass $\left(\mathrm{t} \mathrm{ha}^{-1}\right)$. Nitrogen harvesting index (NHI)

NHI represents the efficiency of absorbed nitrogen being transferred from harvested parts of crop to seeds (Hasanalideh \& Hojati, 2012). Our results showed that the $\mathrm{N}$ rate had no significant $(\mathrm{p}=0.840)$ impact on winter oilseed rape NHI, but the growing season affected it significantly $(\mathrm{p}<0.001)$ (Table 7 ).

Similarly to other parameters characterizing nitrogen use efficiency, the lowest NHI was observed in overly dry $2017 / 2018(46.79-54.53 \%)$, but the highest $(82.57-89.39 \%)$ - in the favorable $2014 / 2015$ (Table 7).

\section{Conclusions}

Nitrogen fertilizer rate had a significant $(p<0.001)$ effect on winter oilseed rape seed yield. Yield increase was observed until nitrogen fertilizer rate N120-N180, but great yield differences between seasons were observed and final conclusion cannot be drawn yet; research should be continued.

Nitrogen fertilizer rate affected $\mathrm{N}, \mathrm{P}_{2} \mathrm{O}_{5}$ and $\mathrm{K}_{2} \mathrm{O}$ removal with oilseed rape biomass significantly $(\mathrm{p}<0.001)$. $\mathrm{N}$ and $\mathrm{K}_{2} \mathrm{O}$ removal with seed yield significantly increased until the rate N120-N180, but that of $\mathrm{P}_{2} \mathrm{O}_{5}$ - until the rate N60-N180.

Nitrogen fertilizer rate affected nitrogen use efficiency (NUE), nitrogen uptake efficiency (NUpE) and nitrogen utilization efficiency (NUtE) significantly $(\mathrm{p}<0.001)$, but it did not have a significant $(\mathrm{p}=0.840)$ effect on nitrogen harvesting index (NHI). By increasing nitrogen fertilizer rate, the NUE, NUpE and NUtE decreased. All the mentioned parameters varied significantly depending on meteorological conditions in the trial year.

\section{Acknowledgments}

The research was funded by the Ministry of Agriculture project 'Determination of maximal fertilizer norms for crops' and by the program 'Strengthening Scientific Capacity in the Latvia University of Life Sciences and Technologies' project Z 24 . 


\section{References}

1. Davis, J. (2007). Nitrogen Efficiency and Management: Nutrient Management Technical Note, 3. Washington.

2. Evans, A., Lucas, D., \& Blaesing, D. (2016). Nitrogen use efficiency (NUE) and tools for farmer engagement: a good reason for being imprecise. In Proceedings of the 2016 International Nitrogen Initiative Conference: Solutions to improve nitrogen use efficiency for the world, 4-8 December 2016. Melbourne, Australia. Retrieved March 01, 2019, from http://www.ini2016.com/pdf-papers/INI2016_Evans_Ashley.pdf.

3. Gan, Y., Malhi, S.S., Brandt, S., Katepa-Mupondwa, F., \& Stevenson, C. (2008). Nitrogen Use Efficiency and Nitrogen Uptake of Canola under Diverse Environments. Agronomy Journal. 100(2), 285-295. DOI: 10.2134/agrojn12007.0229.

4. Grant, C.A., \& Bailey, L.D. (1993). Fertility management in canola production. Canadian Journal of Plant Science. 73, 651-670. DOI: 10.4141/cjps93-087.

5. Haile, D., Nigussie, D., \& Ayana, A. (2012). Nitrogen use efficiency of bread wheat: effect of nitrogen rate and time of application. Journal of Soil Science and Plant Nutrition. 12(3), 389-409. DOI: 10.4067/ S0718-95162012005000002.

6. Hasanalideh, A.H., \& Hojati, M. (2012). Enhancing yield and nitrogen use efficiency of Brassica napus L. using an integrated fertilizer management. Advances in Environmental Biology, 6(2), 641-647.

7. Jackson, G.D. (2000). Effects of nitrogen and sulfur on canola yield and nutrient uptake. Agronomy Journal. 92, 644-649.

8. Koenig, R., Ashley, H.W., \& Pan, W. (2011). Canola Growth, Development, and Fertility. Washington: Washington State University.

9. Moll, R.H., Kamprath, E., \& Jackson, W.A. (1982). Analysis and interpretation of factors which contribute to efficiency of nitrogen utilization. Agronomy Journal. 74, 562-564. DOI: 10.2134/agronj1982. $00021962007400030037 \mathrm{x}$.

10. Pellet, D. (2002). Oilseed rape varietal response to nitrogen fertilizer. GCIRC Bulletin, 18, 1-2.

11. Podgornik, M., \& Pintar, M. (2007). Cause of nitrate leaching from agriculture land in Slovenia. Acta Agriculturae Slovenica. 89, 207-220.

12. Rahimizadeh, M., Kashani A., Zare-Feizabadi, A., Koocheki, A.R., \& Nassiri-Mahallati, M. (2010). Nitrogen use efficiency of wheat as affected by preceding crop, application of nitrogen and crop residues. Australian Journal of Crop Science. 4(5), 363-368.

13. Ruža, A., Gaile, Z., Balodis, O., Kreita, Dz., \& Katamadze, M. (2012). Slāpekḷa mēslojuma normu ietekme uz barības vielu izmantošanās rādìtājiem ziemas rapsim (The impact of nitrogen fertilizer norm on indicators of nutrient use for winter oilseed rape). No Zinātniski praktiskās konferences: Zinātne Latvijas lauksaimniecības nākotnei: pārtika, lopbarība, šḳiedra un enerǵija, 23.-24. Februāris 2012. Jelgava, Latvija: LLU. 86-90. lpp. (in Latvian)

14. Šidlauskas, G., \& Tarakanovas, P. (2004). Factors affecting nitrogen concentration in spring oilseed rape (Brasica napus L.). Plant Soil Environ. 50(5), 227-234.

15. Szczepaniak, W., Grzebisz, W., Barlog, P., \& Przygocka-Cyna, K. (2017). Mineral composition of winter oilseed rape (Brassica napus L.) seeds as a tool for oil yield prognosis. Journal of Central European Agriculture. 18(1), 196-213. DOI: 10.5513/JCEA01/18.1.1879. 